\title{
THE LGBT COMMUNITY AS A STAKEHOLDER IN COMMUNICATING CORPORATE SOCIAL RESPONSIBILITY: AN ANALYSIS OF SELECTED CASE STUDIES
}

\author{
MARTA SZYNDLAR \\ EMILIA WĄSIKIEWICZ-FIRLEJ
}

\begin{abstract}
Corporate Social Responsibility (CSR) has become an indispensable element of corporate communication. Engagement in social initiatives enables companies to stabilise their positive image, present their values and communicate with stakeholders. Although in recent years the LGBT community has more and more frequently been the addressee of such corporate actions, this theme has rarely been explored by scholars. The present paper aims to investigate how corporate initiatives related to CSR are communicated to the LGBT community as one of the corporate stakeholders. Due to the scarcity of subsequent research, the current qualitative study is of an explorative character and has taken the form of a case study. Three brands renown for addressing the LGBT community, i.e. Ben and Jerry's, Levi's and Absolut Vodka, have been selected for the study, which analyses the relevant communication practices. The study primarily aims to specify the image of the LBGT community emerging from the campaigns analysed and to identify the communication channels and tools applied. Additionally, it also attempts to scrutinise the outcomes of these activities and their impact on corporate reputation as well as the perception of the LGBT community in a wider social context.
\end{abstract}

Key words: corporate communication, corporate social responsibility, LGBT stakeholders

\section{Corporate communication and its key terms}

Corporate communication is defined by van Riel (1995: 26) as "an instrument of management by means of which all consciously used forms of internal and external communication are harmonised as effectively and efficiently as possible, so as to 
create a favourable basis for relationships with groups upon which the company is dependent". According to Cornelissen (2004: 23), "[c]orporate communication is a management function that offers a framework and vocabulary for the effective coordination of all means of communication with the overall purpose of establishing and maintaining favourable reputations with stakeholder groups upon which the organization is dependent."

The basic definition of stakeholders, as put forward by Freeman, is "any group or individual that can affect or is affected by the achievement of a corporation's purpose" (Freeman, 2004: 229). The idea behind this thought is simple: any group that, by its thoughts and actions, might influence the undertakings of the company in any way must be taken into consideration while making any strategic plans, including those regarding communication. What differentiates the concept from the earlier management strategies is the idea of taking the whole groups of potential recipients into consideration, arising with the dynamic business development and its increasing influence on the environment.

According to van Riel and Fombrun (2007), any company has five key stakeholder groups: employees, customers, investors, government, and the public. In Cornelissen's (2004: 59) view, the stakeholders who must be taken into account include: governments, investors, political groups, customers, communities, employees, trade associations and suppliers. It is therefore necessary to implement strategies to deal with each of them. However, as every company has multiple stakeholders, it is impossible to consciously take into consideration everyone who receives the message. Thus, it is necessary to select and then segment the target groups who are most relevant for the company's undertakings (van Riel and Fombrun, 2007: 162).

The external stakeholders, namely the public or audience, might also be categorised into four groups (Hoffman and Ford, 2010: 65-67). The enabling audiences encompass those who are parts of "legislative bodies, regulatory groups and, depending on the organization, stockholders" (ibidem: 65). The organisation depends on them in formal and financial ways as it is impossible for a company to function without lawful confirmations. The second group are functional audiences, which "are composed of individuals or groups that help the organization function on day-to-day basis. This includes employees, customers and suppliers" (ibidem: 66). The third group are normative audiences, embracing organisations which share similar interests, goals and are affected by the same occurrences. Therefore, they closely observe the fellow organisations in order to control the situation or learn from them. The fourth group, called diffused audiences, are those who are not closely connected with the organisation but might still hold an interest in the company, for example "individuals in the surrounding community, in interest groups concerned with human rights or environmental protection, voters, and representatives of the media." (ibidem: 66).

At one point, any company is confronted with the necessity to define their mission, core purpose and generally answer the question about "who they really are" 
and communicate this message effectively to both internal and external agents. Therefore, a need to properly determine and share the company's identity arises (van Riel and Fombrun, 2007). As the International Corporate Identity Group puts is, "[c]orporate identity is a strategic issue", which "is concerned with all of an organization"s stakeholders and the multi-faceted way in which an organization communicates" (IS1).

Cornelissen (2004: 71) differentiates between corporate identity and organisational identity:

[c]orporate identity is $(\ldots)$ concerned with the construction of identity to differentiate a company's position and offerings in the eyes of important stakeholder groups. Organizational identity, on the other hand, is founded in deeper patterns of meaning and sensemaking of people within the organization and leads to shared values, identification and belonging.

It means that the organisational identity lies at the core of the company, defining the very concepts of what it is and what its mission is, while corporate identity additionally deals with the issue of how to communicate these values to the stakeholders via different means.

However, this distinction is not always made and the two terms might be used interchangeably. For example, Balmer and Gray (2000: 256) state that "[c]orporate identity is the reality and uniqueness of an organisation which is integrally related to its external and internal image and reputation through corporate communication". In a similar way, Aust (2004: 516) points out that "[o]rganizational identity refers to those core, distinctive, and enduring features unique to an institution". The definitions are based on the same premise as the authors do not draw a distinction between an "organization" and "corporation". This point of view seems to prevail (von Riel and Fombrun, 2007; Hoffman and Ford, 2010; Balmer and Gray, 2000; Dutton et al., 1994).

As mentioned above, the company has to sustain a specific identity by skilfully combining images and messages it sends. The accumulation of those creates a certain impression of the company in the minds of the stakeholders. Brown and Humphreys (2006; cited in Kenny et. al., 2011: 127), differentiate between the notion of identity, addressing the phenomenological question of:"Who are we as an organization" and intended image, standing for the organisation's desired perception, versus construed image, which refers to how an organisation believes to be perceived by others. The duality of image is also observed by Puppel (2016) who discerns static and dynamic aspects of image. In its static dimension, image refers to the self-awareness of an individual's or institution's identity, while its dynamic dimension is understood as continuous engagement in undertaking interactivecommunicative activities in order to make a desired impression on others. This signalling might be either honest or dishonest (Puppel, 2016: 111), depending on the communicator's intended persuasive goals. 
The concept of reputation, on the other hand, is understood as the actual perception of an organisation by others. Gray and Balmer (1998: 697) observe that corporate reputation involves an evaluation of "the company's attributes" and throughout the years it undergoes certain transformations "as a result of consistent performance, reinforced by effective communication, whereas corporate images can be fashioned more quickly through well-conceived communication programmes". In other words, reputation appears more stable that image and has a tangible market value that translates into a competitive advantage (Gray and Balmer, 1998: 696).

We can therefore state that "corporate reputation is arrived at by considering the sum total of images an individual has accumulated over a period of time that help that individual form an opinion about an organisation" (Löwensberg, 2006: 254). Fombrun (1996: 72) in his widely regarded definition states that reputation is "a perceptual representation of a company's past actions and future prospects that describe the firm's overall appeal to all its key constituents when compared to other leading rivals", taking into account the issues of consistency and uniqueness. Van Riel and Fombrun (2007: 40) hold that "[corporate reputation] captures all effects that brands and images have on the overall evaluations which stakeholders make of the companies. (...) Organizations with particular brands and image attributes therefore develop greater or lesser reputations". Due to the fact that reputation can be measured by different means, it is an indicator whether the company communicates with their stakeholders in a proper way.

\section{Corporate Social Responsibility}

Corporate Social Responsibility (CSR) is one of the forms of corporate communication. It is strictly related to the presence of outside stakeholders, who expect the company to take their environment into account as opposed to simple accumulation of profits, as well as the fact that rapidly developing societies expect a greater quality of actions from the companies, whose ethics might have a significant impact on their financial performance.

While the idea has been subject to a large number of broad analyses, it is necessary to provide a brief explanation of the concept. As Gray et al. (1987: 4) define it, "corporations should have the responsibilities for actions which do not have purely financial implications and which are demanded of an organisation under some (implicit or explicit) identifiable contract". Cornelissen (2004: 186) adjusts this definition to: "[a]ctions that do not have purely financial implications and that are demanded or expected of an organisation by society at large, often concerning ecological and social issues". This means that simple market calculations are just as relevant as the impression the company makes on its stakeholders. As Cornelissen (ibidem: 63) mentions: 
[t]he impetus for CSR came with a recognition of the need for business to deliver wider societal value beyond shareholder and market value alone, and has in recent years become more pertinent through expectations voiced by the international community, NGOs, pressure groups, as well as many market parties.

A simpler definition is provided by Tench (2006a: 97), who deems CSR "an organisation's defined responsibility to its society(ies) and stakeholders". The "defining" organ might be either legal regulations or simply a society's expectations.

Additionally, two crucial terms connected with CSR need to be additionally defined for the sake of this paper: Corporate Community Involvement (CCI) and Cause-Related Marketing (CRM). CCI programmes are "tactical approaches organizations plan to discharge their corporate social responsibility policy. They may be viewed as the organisational recognition that businesses cannot survive unless there is a prosperous community or wider society from which to draw both employees and trade" (Tench, 2006: 356). CRM, on the other hand, stands for "where a company associates a marketing promotion with a charitable cause" (Hart, 1995: 219). It "encompasses balancing the legitimate demands of stakeholders (namely customers, employees, environment, suppliers/dealers, regulators, (local) community and shareholders); accepting accountability for marketing decisions; and, integrating ethical and societal obligations into the firm's marketing activities" (Murphy et al., 2013: 92).

\section{The LGBT community as a stakeholder}

The LGBT (Lesbian, Gay, Bisexual and Transgender) community can be treated as one of the stakeholder groups for the companies. Being ascribed the status of a minority with a set of shared characteristic as well as common experience of discrimination and social oppression, the community is often engaged in various NGOs. As such, it can be categorised as a distinct group of company stakeholders with very specific needs.

The LGBT community holds a particular position even among other minorities as it still remains a social taboo and the negative views towards it are not only widespread, but, at least in some places, commonly accepted as a norm. While the attitudes towards the LGBT community have been changing, LGBT-friendly policies are still considered controversial and risky (Pichler et al., 2018: 265), as they might lead to a boycott or shareholders' withdrawal. For a considerable amount of time, the LGBT community has been framed as "medical abnormality" and "socially deviant" by "scientific" research concerning organisations and only since the 1970 s has the characteristic shifted towards "collective identity" along with the development of the gay rights movement, even though it suffered a considerable setback during the AIDS crisis in 1980s (Anteby et al., 2014). The discussion about LGBT 
issues started resembling the framework recognised from the ethnic minorities discourse, underlining the shared identity, social disadvantage and common stigma (ibidem: 11). This framework is still upheld today, which can be observed in the narrations of NGOs concerned with the LGBT community.

The research of LGBT stakeholders focuses mainly on either strictly marketing aspects (therefore it considers them mostly as potential buyers) or concerns the situation of LGBT workers in the workplace. The first approach stems from the idea of target marketing, which "refers to the identification of a set of buyers sharing common needs or characteristics that a company decides to serve". It has been showed that a group which is specifically referred to can develop a stronger affinity for the brand (Aaker et al, 2014: 2). Another important issue concerns the fact that with little to no representation in the media, the LGBT community is prone to a strong identification with whatever they see (Gross, 2001) and, if utilised in marketing issues, it leads to outstanding brand loyalty (the underprivileged community willing to stay faithful to those who support it) (Angelini et al., 2010: 485). Han and Tsai (2015: 155) underline LGBT's commercial attractiveness - as gay people tend to have a considerable spending power, which, combined with the aforementioned brand loyalty and the fact that this market has been notoriously underutilised, can make up for a good target audience. According to the authors, in most cases even the attempted boycotts failed to undermine the benefits of target marketing to the LGBT community.

The discourse about LGBT employees shares a lot of common ground with the marketing discourse. Creating LGBT-welcoming policies can be perceived as a socially responsible decision considering their underprivileged status. They can also bring financial benefits, which significantly improve LGBT employees' work performance (Pichler et al., 2018). The fact that the community faces unique forms of discrimination and is widely unresearched, still places it at a vulnerable position. As Ragins (2004: 111) states:

LGB workers constitute one of the largest minority groups in our workforce, yet remain the "invisible stigmatized citizens" in our workplaces and communities. This treatment results in tremendous personal, social and economic loss. For our workforce and communities to prosper, we need to make this invisible group visible by creating safe havens that welcome, value and protect LGB workers.

It has to be underlined that research on CSR initiatives aimed at the LGBT community, which focuses not on the potential profit, but simply on the ways in which companies approach the topic, is scarce. The LGBT community as stakeholders in research has mostly been perceived in terms of potential customers, employees, or pressure groups, and not simply in terms of an underprivileged social group who might socially benefit from the company's actions. 


\section{Research design and methodology}

As mentioned above, the topic of CSR actions dedicated to the LGBT community still remains an unexplored subject. As such, the already existing communication processes fail to be well documented, not to mention divided into categories and catalogued. Additionally, the communication aimed specifically and exclusively at the LGBT community still remains scarce in comparison to other topics popular within CSR, e.g. ecology or gender equality.

Due to an evident scarcity of relevant literature and research, the qualitative study undertaken will be of an explanatory nature. The characteristics of such an approach include a flexibility of research design, wide range of data which can be analysed, the natural setting of the observed data (not influenced at all by researchers), small sample sizes (that can be in exchange thoroughly analysed) and interpretative nature (Dörnyei, 2007: 37-38). Such a choice is suitable for the topic on which little is known and is yet to be widely researched. The research method chosen is the case study, which might help identify certain patterns and pave the path to further, larger-scale studies. The case study presented here is of a multiple (or collective) type, where a "number of cases are studied jointly in order to investigate a phenomenon or general condition" (ibidem: 152), namely the way companies communicate to the LGBT community as their stakeholders.

A lack of previous studies and categorisations demands their initial investigation in order to formulate detailed research questions. As Dörnyei (2007: 308) states, "[s]uch situations necessitate exploratory investigation that helps us to map the terrain first and fine-tune our specific research angle later in the project". Therefore, this study is meant to provide a framework for future research concerning the topic.

\subsection{Research aims and questions}

The study presented in this paper is a comprehensive analysis of various messages communicated by three brands: Ben and Jerry's, Levi's and Absolut Vodka. While this is a relatively small corpus, it is definitely consistent: all three companies have been outwardly and exclusively (without combining LGBT issues with any other in a single message) addressing the LGBT community as their stakeholder. Therefore, the data gathered about these three companies can shed some light on how such communication might look like in practice. Considering the nature and forms of the messages, the following research questions have been posed:

RQ1: Do the companies mainly engage in CCI or CRM?

RQ2: Which channels and tools are used? 
RQ3: What is the depiction of the LGBT community?

RQ4: What is the relationship of the company with the LGBT stakeholders?

RQ5: What are the outcomes of the campaigns?

RQ6: How do LGBT-specific CSR actions influence a company's identity and reputation?

\subsection{Sampling strategy}

To collect the samples concerning the external messages sent by the companies, each of the companies' official websites was visited and browsed, with a particular focus on the section about values. All sections containing materials about the LGBT community were found and accessed. The study also attempted to take a look at other language versions for comparison but, due to the language barrier, the analysis was limited to the Polish, German and Japanese websites. Next, websites of the general owners of the brand were also accessed and investigated in a similar way. Then social media channels were investigated, with the focus on Facebook, Twitter and YouTube pages. To determine the internal communication of the companies, pages addressing potential employees as well as job offers were analysed. Messages about the companies were gathered by means of Google search (company's name and "LGBT" in order to investigate how a given brand is perceived in this context). This selection was motivated by the fact that Google had the biggest outreach and therefore proved to be the most accessible and widely read by the general public. All in all, the investigation was supposed to encompass the most visible, media-covered parts of the company's communication to the LGBT stakeholders.

Before the analysis, it is important to stress that the LGBT-related initiatives are only a part of the companies' CSR conduct. The concern for LGBT rights and welfare is usually framed within the general theme of "diversity and inclusion", which is frequently expressed in the description of the companies' norms and values (Wąsikiewicz-Firlej, 2017: 282-283). While not all companies which voice their commitment to this particular cause outwardly mention the LGBT community as one of the beneficiaries of their inclusive policies, given the immense popularity of the declaration of diversity and acceptance (ibidem), it can be assumed that any and all "minorities" should be welcomed. What differentiates the companies chosen for this case study from the large group of companies which mention their devotion to these values is the fact that the LGBT community appears to be one of the main benefactors of their social undertakings, ranked first among the diversity-related, or even generally society-related, causes that the companies support for a prolonged period of time. This approach allowed them to establish a connection with the LGBT stakeholders and become identified as gay-friendly companies, as opposed to businesses which opt for singular LGBT-related actions discontinued after a while, e.g. Burger King and its Pride Whopper (IS2). 
Another issue which is important to stress is a discrepancy between the companies 'theoretical support for the LGBT issues and their actual marketing and CSR actions mostly targeting people in same-gender relationships, particularly gay men, with transgender people being rather excluded. While this issue is not investigated in this study, it is crucial to remember that whenever "LGBT" is mentioned, it often transfers factually only to "gays and lesbians". The full acronym is used by companies possibly only to avoid potential backlash. One of the reasons for this status quo might be the fact that the market niche of transgender people is largely unstudied and therefore more risky to access.

\section{Results}

\subsection{Ben and Jerry's}

Ben and Jerry's is an ice-cream manufacturing company founded in 1978 in Burlington, Vermont. In 2000 it became part of Unilever and today it functions as its full subsidiary. The company prides itself on its ice-cream - frequently called "euphoric" - but also continuously emphasises its devotion to social responsibility. In fact, it is a part of a network called Certified B corporations, which include "businesses that meet the highest standards of verified social and environmental performance, public transparency, and legal accountability to balance profit and purpose. B Corps are accelerating a global culture shift to redefine success in business and build a more inclusive and sustainable economy" (IS2). Their mission is to help the government and NGOs in solving the society's most challenging problems. Ben and Jerry's devotion to their social mission is evident from their main website, where the "Values" section is as visible as the section about their products (IS3). Ben and Jerry's colourful and easily accessible website contains numerous sections dedicated to the company's principles. The largest one is devoted to environmental sustainability - the focus is placed on fair purchasing and manufacturing as well as "giving back practices" regarding the local communities (IS4). However, in the section "Issues we care about", eleven particular initiatives are listed, along with "LGBT equality".

The detailed description of the "LGBT equality" section consists of a chronological list of activities Ben and Jerry's have undertaken in previous years, starting as early as 1989 with introducing equal benefits for employee's partners, regardless of their sex. Other items on the list include: event sponsorships, grants (which, as the official website of Ben and Jerry's foundation proves, are still being distributed to multiple organisations which list the welfare of the LGBT community as one of their priorities (IS5) and extensive political involvement, including signing an official letter to the Supreme Court in support of same-sex marriage (IS6). It also indicates that the company scored maximum points in the Human Rights Campaign's Corpo- 
rate Equality Index Rating. The list therefore depicts the company as a politically engaged, socially sustainable supporter the LGBT rights.

Interestingly, investigating other language versions reveals that the LGBT-related issues appear on every single one; "marriage equality" appears to be the most frequent. For example, Poland or Japan both have this issue listed among as few as four others, even though in neither of these countries same-sex marriage is legal and LGBT community is commonly socially opposed. It can be therefore stated that LGBT equality and specifically same-sex marriage are the core of Ben and Jerry's social mission. The Polish website is worth mentioning due to the fact that the company's support for the community is announced as early as on the main page (IS7).

Ben and Jerry's have also started cooperating with two local NGOs fighting for LGBT equality, "Miłość Nie Wyklucza" and "Wolnotariat Równości", very soon after appearing on the Polish market (IS8).

Ben and Jerry's owner company, Unilever, features a section called "Sustainable living" which begins with a credo: "Our vision is a new way of doing business - one that delivers growth by serving society and the planet" (IS9). It focuses mostly on environmental sustainability, however, it also includes a section called "Enahncing livelihood" which focuses mostly on human rights, mainly in the context of employers of less privileged countries, and women's empowerment (IS10). While the general theme of sustainability and equality is definitely retained, the LGBT community is not directly addressed.

When it comes to social media, Ben and Jerry's run an active blog available in all language versions. The notes are plentiful and often humorous, including quiz tests. The LGBT-community-related posts do not only report on the company's actions, but also provide general information crucial to the LGBT community, often taking political stands and encouraging the readers to take action, e.g. the celebration of transgender day of visibility (IS11), "11 Proposed Laws that the LGBTQ Community Needs ASAP" (IS12) or "9 Ways the Trump Administration Has Proven It Doesn't Care about LGBTQ People" (IS13). The posts are politically charged, yet presented in a light, accessible format.

Ben and Jerry's also run a YouTube profile. While a great portion of their videos concern simply promotional clips or "ice cream hacks", there is a large section devoted to their values. The featured playlists are "Democracy is in your hands" and "Climate Justice", however, LGBT-connected videos appear too, including a clip called "Love is Love", featuring a couple of two girls talking about their relationship and desire to marry each other (IS14). The LGBT-related clips date back to 2015 when marriage equality was introduced in the USA and have not been updated since. Regional playlists, e.g. Polish or British, contain clips documenting Ben and Jerry's actions undertaken in the given countries.

Other social media of Ben and Jerry's - Facebook, Twitter and Instagram operate in a similar manner. The content reflects everything that is published on the 
official websites and their posts and tweets frequently link to the Ben and Jerry's blog, simply informing about their products and actions in a shorter form, each accompanied with a colourful picture or photograph. The LGBT-related topics are either limited to similarly framed reminders and invitations to the blog (IS15) or posts, which do not relate to any particular current issue but express support with a few words and a graphic (IS16). No interactive, Internet-specific campaign, which would exclusively or mostly utilise social media, seems to have been attempted.

When it comes to the internal corporate communications, Ben and Jerry's recruitment section is listed under "Jobs" on the main page. Employees are reassured to be treated according to the same values that the entire company draws on. On the bottom of the website, the following statement can be found:

All qualified applicants will receive consideration for employment and will not be discriminated against on the basis of race, color, religion, sex, sexual orientation, national origin, age, disability, protected veteran status, or other protected class in accordance with applicable federal, state, and local laws. Unilever takes affirmative action in support of its policy to and advance in employment individuals who are minorities, women, protected veterans, and individuals with disabilities. (IS17)

While Ben and Jerry's employee-oriented page is fairly simplistic, more information can be found on Unilever's official website, where job offers for their brands are posted. It focuses on the general spirit of equality, fair chances and sustainability (IS18). At the moment of writing this paper (April 2019), the list of specific benefits offered to the employees could not be accessed due to a website malfunction. All in all, despite the fact that the LGBT community is not directly addressed, multiple declarations of all employees' equality can be found. Additionally, as it was mentioned above, Ben and Jerry's claim to be one of the first companies to offer benefits to their employee's same-gender partners that clearly points to a long tradition of the company's equal treatment.

Ben and Jerry's grabbed the media attention with a few LGBT-connected actions which went viral, with a varying degree of positive reception. One of their most famous initiatives is re-naming their famous ice-cream flavours with puns concerning same-sex marriage. For example, after marriage equality had been introduced in the USA, the company renamed their most popular flavour, Chocolate Chip Cookie Dough, as "I Dough, I Dough" (Fig. 1).

However, Google search leaves no doubt that their most viral campaign was a 2017 action, when Ben and Jerry's Australia banned buying two scoops of ice cream of the same flavour to their customers in support of the same-sex marriage. The official statement from the website reads as follows:

Imagine heading down to your local Scoop Shop to order your favorite two scoops of Cookie Dough in a waffle cone. But you find out you are not allowed-Ben \& Jerry's has banned two scoops of the same flavor [...]. You'd be furious! [...] But this doesn't 
even begin to compare to how furious you would be if you were told you were not allowed to marry the person you love. (IS20)

Described as either "weird" or "creative", the campaign evoked a lot of mixed reactions and commentaries (IS21). The spokespersons for Ben and Jerry's emphasised the need for actual, and not just artificial, sustainability and community outreach, trying to stay "genuine" even as Unilever's subsidiary (IS22).

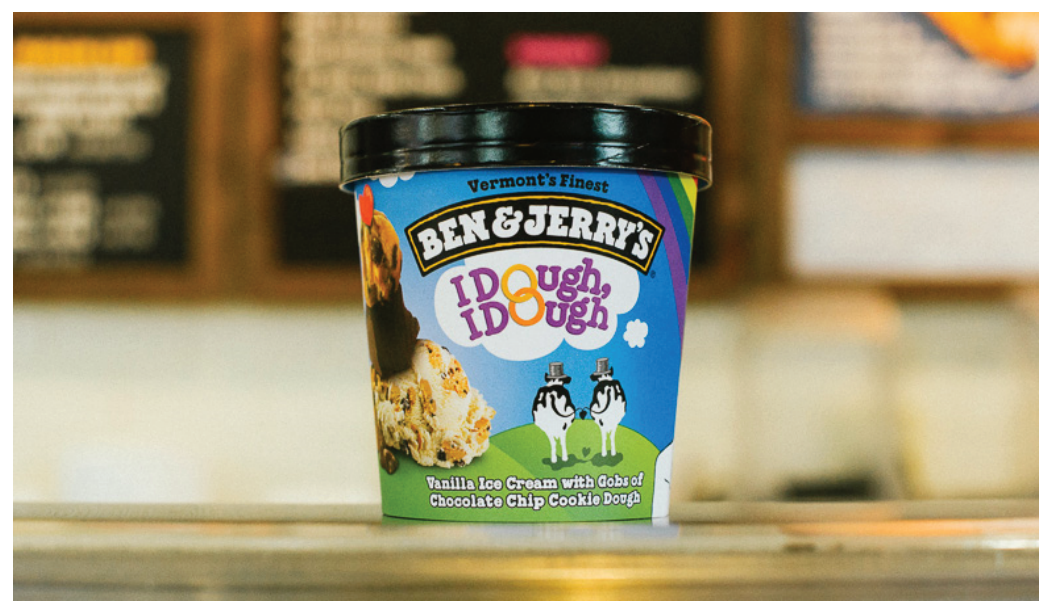

Figure 1. Source: IS19.

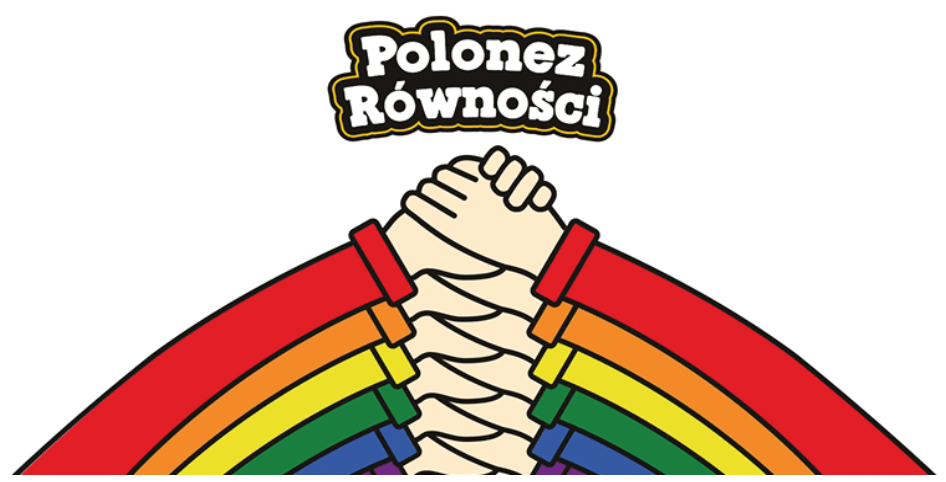

Figure 2. Source: IS24

In Poland, Ben and Jerry's actions included putting up a lightshow depicting a rainbow on "Plac Zbawiciela" to commemorate the tangible rainbow installation which used to be located in that area and unintentionally became a symbol of social fight for LGBT rights (IS23), as well as a happening, "Polonez Równości", during 
which the students of one of Warsaw's high schools performed a traditional dance on their prom in same-gender pairs as a sign of support for the LGBT community (see Fig. 2).

Summing up, Ben and Jerry's mainly focused on tangible actions, which include community support, political engagement and socially-responsible marketing. The actions are not limited to the countries where LGBT rights are already widely recognised and respected as the company claims to be one of the upstanders in the fight to obtain them. Social media fail to play an important role in their CSR strategy and provide simply an informative function.

\subsection{Levi's}

Levi's is a brand of Levi Strauss \& Co., which was founded in 1853. Other brands include Dockers and Denizen. According to the corporate website, the company is a global leader in jeans wear (IS25). While the official website of the brand functions mostly as an online store, the section related to the company and its values is easily accessible. However, the company's sustainability and devotion to diversity is exposed on the main website of Levi Strauss \& Co., which makes this particular section even more visible than the information about their products (IS26). It is therefore evident that the company's policy is based to a great extent on CSR and the communication of thereof, which includes fair and environmentally friendly business practices and caring about their communities and employees.

On the bottom of Levi's brand website, a "values" section can be found. It is divided into three parts: environment, community and factories. Under "community", six different causes are listed. One of them is "LGBTQ + Pride". In the short text accompanying this segment, Levi's explains its devotion to the cause by naming itself one of the first companies to have supported the fight with HIV/AIDS and mentioning its "Pride" appearances, community donations as well as their yearly "Pride Collection", which will be described in detail below. It is also accompanied by a video including testimonies of LGBT people speaking about not being afraid of showing who they really are. Notably, all of them are wearing Levi's clothes (IS27).

Exploring the website in other language versions proves that the content is not customised - the texts about values are identical in other English-speaking countries, Polish or German versions are simply translated into the native languages. Interestingly, the Japanese version of the website is devoid of any "about us" section whatsoever. While other countries have not been investigated due to the language barrier, based on the aforementioned examples it is evident that Levi's does not operate locally at all, only supporting USA-based causes.

On the corporate website of Levi Strauss, the issue of LGBT community fails to have a separate link devoted just to this cause. The dominant subject is environmen- 
tal sustainability as well as giving back to the communities by "valuing people over profits". In the category called "Values in action", and then "Social impact", their methods of community involvement can be found. Levi Strauss claims to enable their employees to volunteer as well as fight for the causes which they care about (IS28). The section about profit re-distribution is decorated with a photograph of rainbow-themed accessories and under the headline "Equality" there is a link to blog posts about LGBT community - however, it is not mentioned by name in the original text (see Fig. 3).

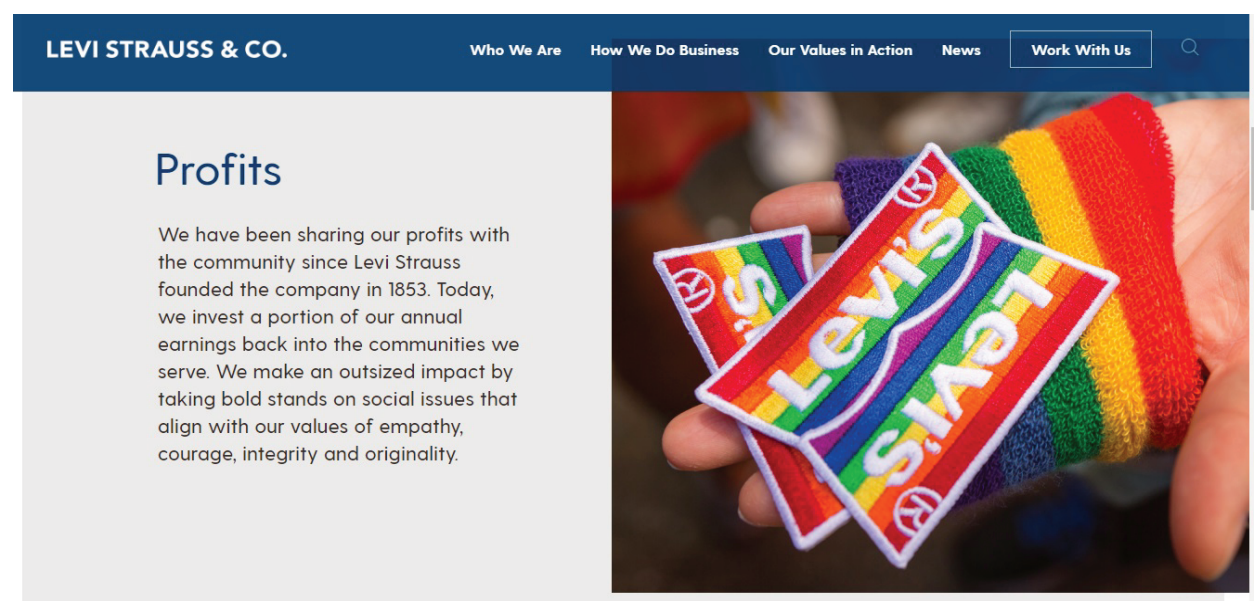

Figure 3. Source: IS29.

Levi Strauss also prides itself on being a long time supporter of LGBT-related causes. The company claims to have helped funding one of the first AIDS clinics and cooperated with organisations such as Human Rights Campaign and Stonewall. It is engaged in politics by supporting anti-discrimination and marriage equality legislations (IS30) and has also pioneered in offering benefits for their LGBT employees (IS31). Moreover, it has been placed at the top of the HRC's Corporate Equality Index Ranking. Levi's also runs its own foundation where it claims to donate, among other causes, to HIV/AIDS related initiatives as well as contribute to the development of "pioneers of justice" who deal with LGBT-related issues as well. Levi's claim that this action positions them as innovators in terms of community relations, because it enables to exert a long-lasting impact and additionally reinforce the issues Levi's stands behind (IS32, IS33).

As an employer, Levi Strauss further underlines their devotion to equality and inclusiveness. On their "Work with us" page, there is a specific section called "A Diverse and Inclusive Culture" (IS34), where the company reassures to consider 
these two values crucial in creating their business. Not only do they assure payment equity and diverse hiring process, but also promise to be aware of unintentional biases and attempt to combat them. Additionally, Levi's has been scoring HRC's Corporate Equality Index for sixteen consecutive years (IS35). The "work with us" section is generally rich in content and corresponds with the same values that can be found in other sections of the website, which were described above.

When it comes to the social media, there are also two blogs related to Levi's: one on the brand's main site and one on the general Levi Strauss website. While the first one mainly reports on things connected with clothing and only mentions LGBTrelated issues in relation to the Pride Collections (IS36), the second one also informs of CSR initiatives undertaken by Levi's. All political and social news have a direct connection with the brand, e.g. the celebration of 2018 coming out day served as an opportunity to remind of Levi Strauss' inclusiveness and undertaken initiatives (IS37). The blogs are easily accessible, yet not particularly featured on the main page.

Levi's social media accounts, like Facebook, Twitter and Instagram, serve mostly to present the company's products and link its online shop or post a brief reminder about one of the campaigns they currently run, both fashion and CSR ones. There are no social-media-specific initiatives, the posts and tweets function more as an encouragement to follow the website and visit retail stores (IS38, IS39).

YouTube channel works in a similar way; the videos published are mostly related to specific campaigns. What seems particularly noteworthy from the point of view of this paper is a series of videos from the "2018 Pride Collection" campaign, which featured voices of multiple members of the community speaking out about their lives and their desire and courage to stay true to themselves. Apart from the official commercial, which can also be accessed on Levi's website, the channel promotes extended, individual videos featuring the stars of the campaign, talking about their issues in depth while dressed in Levi's clothes (IS40). This personal approach to the LGBT issues has been used before in other social campaigns run by LGBT NGOs, so it can be treated as a tribute to this type of communication. Apart from that campaign and short videos advertising last year's collections, other LGBT-related topics fail to be featured.

However, taking into consideration the amount of media coverage, Levi's is most known for its annual "Pride Collection", which has been released since 2014. The collection features the rainbow and pride-themed clothing, each surrounded around a theme.

Starting with just a simple collection of a few unisex items with rainbow patterns in 2014 (IS41), it later launched the "Levi's x Stonewall" collection in 2015, featuring T-shirts and a patched jacket (IS42), followed by the "Levi's x Harvey Milk Foundation" collection in 2016, based on the slogan "We will never be silent" (IS43), the 2017 "Worn with Pride" collection in cooperation with both of the 
aforementioned foundations, centred around the slogan "Fight Stigma" in commemoration of the AIDS crisis victims (IS44), and the 2018 collection promoting a "I AM" t-shirt, communicating the brand's desire for everyone to be able to express themselves, followed by a huge marketing video campaign, which featured confessions of different members of the LGBT community (IS45). Joined by the pride-themed decoration of their retail stores, the company claims to celebrate their long-lasting support for the LGBT community with these "Pride" month collections. It is important to notify that according to Levi's, the entire net profit is donated to the "Harvey Milk Foundation" and "Stonewall Community Foundation". This act of charity has been protecting Levi's from being accused of pinkwashing and influenced the positive acceptance of the initiative (IS46).

It is also important to point out that Levi's policy of reaching out to the LGBT community has suffered a backlash in 2018 after a journalistic investigation concerning the manufacturing places of Pride collections from various companies. According to "The New York Times" and "BBC News", it was discovered that a lot of such apparel is produced in countries where homosexuality is heavily discriminated against or even punishable. Levi's has admitted to have factories in countries such as China, India, Madagascar and Mexico. However, the company managed to avoid crisis on two accounts: firstly, the company assured to be actively engaged in local causes supporting the LGBT community by e.g., donating to an Indian organisation fighting against their ban on equality; Levi's spokesperson also stressed that the company had a "comprehensive workplace code of conduct for manufacturing suppliers".

Following Hoffman and Ford's categorisation of ways of dealing with a crisis, Levi's reaction falls into the strategy of dissociation by drawing a distinction between the company's actions and the countries' policies, positioning themselves as socially engaged peace bringers instead of foreign investors whose money partially supports the budget of the oppressive governments. However, the second and more important reason of why Levi's avoided a crisis situation is that other investigated companies either failed to provide proves of their support for the local LGBT communities the way Levi's did (e.g., Primark, H\&M) or refused to disclose their manufacturing details altogether (Nike, Adidas), therefore breaking one of the rules of crisis management concerning staying silent in the face of a crisis, which proved to be ultimately damaging and ineffective. The media chasing the story, focusing on the "worse" companies, enabled Levi's to come out of the crisis intact, or even gain profit - because their engagement in LGBT causes became publicly disclosed on widely read news websites (IS47, IS48).

Summing up, Levi's based its communication towards LGBT community on socially-engaged clothing lines, attempting to connect social responsibility with regular marketing campaigns. Additionally, Levi Strauss \& Co. is devoted to underlining its ethos of sustainability and equality, LGBT people being one of the beneficiaries 
of its alleged attempts to contribute to their communities. Positioning oneself as politically engaged, unafraid to speak out and a pioneer of change, Levi's managed to gain a favourable reputation among the LGBT community, the proof of which could be the fact that their 2018 "Pride" collection sold almost twice as well as the previous year's one. At the moment of writing this paper (April 2019), the "Pride" collection of 2019 has not yet been announced, but given the lack of major crises, it is fair to assume it will continue to be successful.

\subsection{Absolut Vodka}

Absolut Vodka is produced by the Swedish Absolut Company, which was founded in 1897 and introduced to the American market in 1979. Since 2008, it has been a part of Pernod Ricard, along with five other brand companies. Apart from Absolut Vodka, the company manages Malibu, Kahlua, Absolut Elyx and Our Vodka (IS49). It is known for its long history of bold, artistic designs, which can be found on bottles, posters and videos. Information about Absolut Vodka can be found either on the product-focused website, which mostly features information about the vodka itself, or the company's website, where information about the company's history can be accessed.

The product's website is colourful, picture-oriented and easy to navigate. The focus is placed on the products and their multiple editions, drink recipes, and campaign news. The informative value of the website is rather insignificant.

In the section called "Our Story", brief information about the company can be accessed, however, it only serves as a description of the brand's environmental sustainability and its ecological attitude to the entire vodka making process, based on the slogan "one source, one community, one superb vodka" (IS50). Highlighting the ideals of locality and clarity, Absolut released a video called "The Vodka with Nothing to Hide", which displays Absolut employees talking about their company while being completely nude (IS51).

The sections of the website where information about Absolut's support towards the LGBT community can be found are: "Products", "Press" (which links to media room) and "News" (which differ slightly depending on the selection of a regional version of the website).

In the product section "Absolut's iconic product", "Absolut Rainbow", can be found. "Absolut Rainbow" is simply a special edition of the bottle, which is covered in brushstroke-like stripes in the colours of the rainbow. It was created in collaboration with the "Pride" flag creator, Gilbert Baker, and is meant to celebrate the longterm commitment of the brand to the LGBT community (IS52).

The "Press" category, which includes seventeen most recent articles on the international version of the website, features as many as three LGBT-related cam- 
paigns: the aforementioned "Absolut Rainbow Edition" (Fig. 4), "Absolut Equal Love" and "Absolut Drop". The information about "Absolut Rainbow" is identical with this contained in the "Products" section, but it additionally features a quotation from the company's VP of Global Marketing:

Absolut's founder LO Smith, a pioneer for human rights in his time, established his passion for openness in the brand DNA from our launch in 1879. Over 135 years later, we've continued this legacy through numerous programs that support both freedom of expression through the arts, and the freedom be and love whomever you choose through working with the LGBTQ community. The Rainbow Edition marks our ongoing commitment as we are including it as a new permanent bottle into our collection." (IS53).

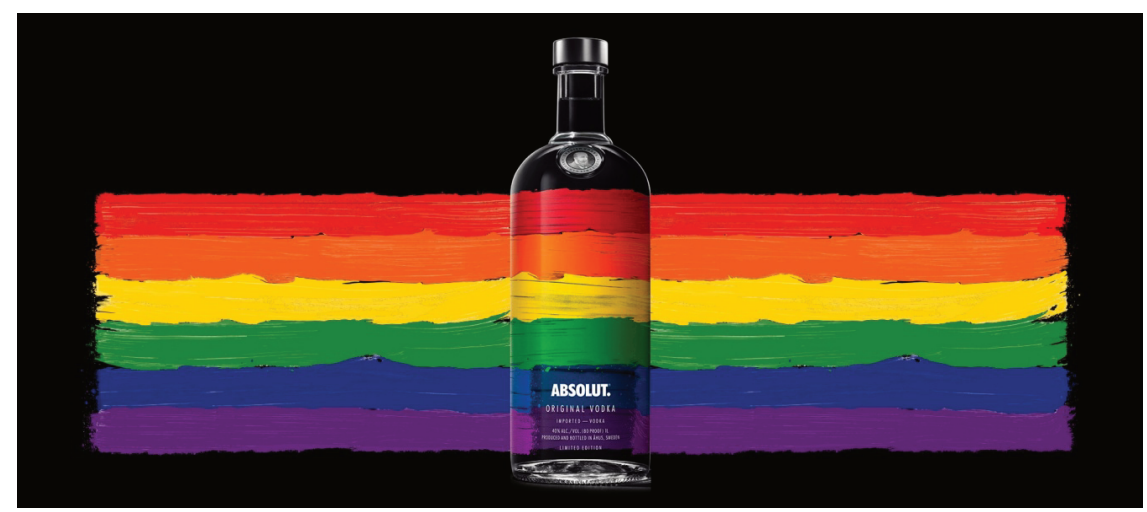

Figure 4. Source: IS53.

"Absolut Equal Love" features a viral Absolut video campaign which shows multiple people of different genders sharing kisses in the evening city scenario. As it is described:

The kisses pay no attention to sexual preference, gender, colour, profession and instead become a testament to equal love. The film reflects Absolut's belief that people should be free to love who they choose and builds on the brand's progressive views and ongoing mission of championing equal love (IS54).

In the accompanying note, Absolut once again underlines its long-lasting support for the LGBT community. Lastly, "Absolut Drop", which is generally equalityoriented and not only focused on the LGBT community, is a special edition of the Absolut bottle printed with an ink extracted from hate-spreading posters from around the world gathered during anti-refugee or anti-LGBT rallies, in the name of turning hate into love. Apart from the special edition bottle, the campaign is accompanied by posters and animated videos (IS55). 
The "News" section, where the content is also rather scarce, LGBT-related news pieces fail to be featured in every language version. For example, they are not available in the global version of the website. However, on the German website, a set of photos from the 2018 "Berlin Pride" depicting Absolut's platform can be found (IS56). The British version features information about a viral campaign called "Kiss with Pride", which was organised in cooperation with "Stonewall UK". As it can be read on the website:

July 27th marks the 50th anniversary of homosexuality being decriminalised in England \& Wales. But homosexuality is still illegal in 72 countries. This project celebrates people from many of those countries who kiss with pride. Kiss With Pride was curated by Absolut, in support of Stonewall, to raise awareness of the fact that same-sex relationships are still illegal in 72 countries. We asked individuals from these countries to come together and portray human love and compassion at its most natural state, by uniting in a kiss. Absolut have championed equal love since 1879, and we are proud to support Stonewall as they empower LGBTQ human rights defenders to campaign for change. (IS58)

The campaign also included cooperation with Snapchat, which provided special "Kiss with Pride" lens; Pernod Ricard offered to donate 1 pound per usage to "Stonewall UK". The pictures of same-gender kisses were featured on official Absolut posters and later displayed during an exhibition (IS57).

The analysis of the materials on the Absolut website reveals that not only does the company fail to provide official confirmation of its long-term support of the LGBT community (all the information about sponsorships, "Pride" appearances or socially responsible marketing is limited to the recent years), nor does it keep an easily-accessible archive of its news and campaigns (older content can be accessed using an outside search engine, but fails to be linked on the website). It can therefore be stated that Absolut fails to have the history of its involvement properly documented and accessible to the general public.

When it comes to the brand's official website, it is important to underline that at the time of writing this paper (April 2019), the website's menu was inaccessible, making it impossible to easily browse or obtain any information. Subpages are only accessible via search engines, which results in a difficult navigation. The company values are featured in the "who we are" section, which is available but not particularly wordy or detailed. The LGBT community also fails to be directly mentioned. "Conviviality, entrepreneurship, mutual trust and a strong sense of ethics" are listed as the most important values; it is also underlined that the company operates prioritising people's welfare as well as diversity and inclusivity. Interestingly, no direct example or evidence of such a conduct is directly listed nor linked (IS58).

Perinord Ricard's official website also fails to feature any LGBT-oriented material. The company's "sustainability" page is generic and fails to focus on one issue, 
providing instead a manifesto attempting to address all issues at once, as well as official company documents serving as proofs of sustainability (IS59)

When it comes to social media, Absolut remains active on both Facebook and Twitter, using the platforms for a lot of interactive contests, including the recent "Absolut Creative Competitions", which searched for new artists to cooperate with the brand. Other posts include simple visual ads, drink recipes or jokes; the LGBT community is always mentioned around its celebrated dates. (IS60).

Another medium important for Absolut is YouTube, where the brand can post videos corresponding with their image as an art-oriented brand. Apart from specific campaign-associated spots or relations from various events, the channels also features films made in collaboration with artists or other creative people whose work is sponsored by the company. When it comes to the LGBT-related content, next to the LGBT-campaign-related videos, like the aforementioned "Absolut Equal Love" and "Absolut Drop", videos showing a surprise engagement party of two female travellers (IS61) or a video supporting the "Nothing but Absolut" marketing campaign featuring two kissing men (IS62) can be found. Notably, Absolut has also featured transgender people in their videos, e.g. a short film centred about a transgender woman as a part of their Absolut Nights campaign (IS63) or a short movie about a transgender woman's experience (IS64).

As far as communication with the company's potential employees is concerned, Absolut has little to offer. Jobs connected with Absolut are listed among others on the side of Pernod Ricards, where, in the official company description, candidates are assured of the company's spirit of inclusiveness without directly referencing the LGBT community. No list of benefits can be accessed. What is important, since 2017 Pernod Ricards has received the maximum 100 points on HRC's Corporate Equality Index (IS65), however, this piece of information fails to be contained on the recruitment page.

However, the aforementioned instances are not the only examples of the support offered by Absolut to the LGBT community. Traditionally putting great emphasis on the company's visuals, which is evident in the multiple collaborations with different artists, both in terms of bottles and visual ads, Absolut has been targeting their posters to the LGBT community since 1981, being one of the pioneers in that respect. In 1981 it made history by printing gay-themed advertisements in the "Advocate and After Dark" (IS66). Since then, Absolut has released multiple campaigns in the form of press ads, posters and billboards addressed specifically to the LGBT community. While some hold just a simple message about equality, e.g. "Absolute Outrageous" celebrating the 30 years of devotion to the LGBT community (IS67), "Absolut Out" billboards celebrating the act of coming-out (IS68), or "Absolut No Label" to fight against prejudice against gender and sexual identities (IS69), other celebrate gay culture and can be only interpreted properly by people interested in it (e.g. coopera- 
tion with openly gay designer Tom Ford and the brand of Tom of Finland (IS70), a popular poster made by Keith Haring, a widely known to the public designer who was also an avid gay rights activist (IS71), posters featuring the tiles of popular LGBT movies meant to appear at the brand-sponsored film festival (IS72), or a poster celebrating the cooperation with GLAAD (IS73)). The library of LGBT-themed posters is rich in design and themes.

The list of event sponsorships provided by Absolut is also very long and includes: "One Mighty Weekend", "The Queer Lounge at Sundance, Broadway Bares", "The Gay Games", "The White Party Miami", "Joining Hearts Atlanta", "Ascension Fire Island and Night of 1,000 Gowns". The company also sponsored numerous LGBT film festivals (IS70) and for many years remained one of the main sponsors of "RuPaul's Drag Race", with the company's PR director at the time appearing in the show (IS74). Absolut has also had a long-term relationship with GLAAD, an organisation fighting for LGBT rights, and still remains one of their main partners (IS75). It also supports the aforementioned Stonewall and allegedly even more exclusive, smaller fundraisers (IS70). While this information is easily accessible, it fails to be easily found on Absolut's official channels.

It is, however, important to stress that all the aforementioned actions and initiatives are limited exclusively to the USA. Absolut fails to run LGBT-inclusive campaigns in each of its markets, for example Poland.

Concluding, Absolut focuses on the socially responsible visual marketing. While they continue to financially support various LGBT-related causes and events, they fail to include any detailed information about these sponsorships on their official channels. Additionally, the company fails to directly engage in political issues and it does not promote LGBT-inclusive campaigns on all its markets. However, their position as one of the pioneers of LGBT marketing and their continuous devotion to the cause made them one of the best recognisable and trusted brand supporters of the community.

\section{Discussion}

Based on the results presented above, this section will address specifically the research questions posed.

\section{1. $\mathrm{RQ}_{1}$ : Do the companies mainly engage in $\mathrm{CCI}$ or $\mathrm{CRM}$ ?}

As it was mentioned before, both CCI and CRM serve as a way to enforce companies' CSR strategies. The both strategies are interchangeably used by the presented companies to a different extent. Ben and Jerry's are definitely focused on the CCI 
actions with only minimum of CRM (the marketing actions mostly concerned a change in their products' name and in all instances the change was made in celebration of LGBT-related events), their area of focus being politics, event sponsorship and support and engagement in the life of local communities. Their product accompanied the actions, but was not directly involved in them. Absolut seems to operate in the middle of the two approaches. Given the experience the company has in supporting the LGBT community, it has been involved in multiple social projects. By financially supporting NGOs, film events, parties, foundations and LGBT artists, it definitely contributed in a great part to the development of local communities and culture. However, in their communication processes, which are going to be further discussed in the sections to follow, they focus on marketing campaigns and constantly display their products in an artistic, creative way, often using LGBT-related images and referring to the company's involvement in the community. In the case of Levi's, the main focus is placed on the advertising of the product and most actions undertaken by the brand are fashion related. The brand, however, also donates to HIV/AIDS funds and other LGBT charities, thanks to which they avoid being accused of pinkwashing and can be considered a real "supporter".

The CCI initiatives are a necessity if a company wants to come across as genuine and build its reputation around the ideals of benevolence and social responsibility, because such an approach helps avoid any accusations of insincerity potentially evolving into a crisis. In all three aforementioned cases, actual proof of actions shaping their local communities and changing them for the better for LGBT people can be found. It must be noted, however, that CRM is also valuable in connecting the conduct to the product.

\section{2. $R Q_{2}$ : Which channels and tools are used?}

In terms of channels and tools used to communicate with the stakeholders, all companies seem to be aware that they exist in the era of social media and that it is crucial to have a brand account on every major portal, however, each of them uses it slightly differently. Absolut is definitely the most interactive when it comes to its relationship with the followers, considering the amount of contests which encourage people to create their own content. One of such actions, "Kiss with Pride", was exclusively aimed at the LGBT community as it was centred on same-gender couples kissing. Still, their poster-based campaigns continue to be their most recognisable, iconic means of communication. Levi's still based on the traditional form of communication with their stakeholders via marketing campaigns, and uses social media mostly to inform about them. Ben and Jerry's social media serve to inform about its extensive activity in "real" world where their representatives support 
LGBT-related events, they also run quite an active company blog, which is often linked to their social media accounts. Therefore, it can be stated that none of the companies was able to fully adapt the two-flow communication model and exchange thoughts with their followers on a seemingly equal level. However, when it comes to the support for controversial issues - and the LGBT community is still considered as such - the exchange of thoughts on a public forum might sometimes end up being a way for people to express their dissatisfaction. Based on some of the available comments sections (e.g. on YouTube), it might be assumed that the risk is real. Engaging the entirety of the company's stakeholders into a dialogue concerning LGBT rights might therefore be a mutually unbeneficial idea. However, the scarcity of more interactive campaigns might prove to be disadvantageous as the time passes and the older forms of communication fail to grab people's attention.

\section{3. $\mathrm{RQ}_{3}$ : What is the depiction of the LGBT community?}

As for to the depiction of the LGBT community in the messages sent by the companies, Absolut and Levi's approached the issue in a similar manner, while Ben and Jerry's adapted a different strategy.

Absolut and Levi's both show racially diverse, predominantly cisgender and almost exclusively young people, who are enjoying their leisure time, typically at the parties (e.g. Absolut). The people presented are free and carefree, out of the closet, living the way they want and finding love. While the both companies engage in political issues, which might be perceived as serious and heavy (fight for marriage equality or support for HIV positive people), the images most broadly distributed are those of freedom and happiness. While the actual political situation might not always correspond with this depiction, such images evoke positive emotions and help establish the image of the brand as the one fighting for the world they portray. The faces of actual people and their personal stories help the consumers identify more with them and, by extension, the brand and the product. On the other hand, such an idealised portrayal could be considered shallow or untrue, remaining a simple, yet largely invaluable marketing tool.

However, Ben and Jerry's hardly ever utilises the images of actual people, usually opting for graphics. Additionally, it does not display lifestyle-connected content but is almost exclusively involved in the discussion on political issues, showing a particular interest in the marriage equality. Heavily engaged politically and dutifully informing of all the issues that might concern them, Ben and Jerry's calls its consumers not only to be themselves, but also to stand up for themselves and fight. While such a strategy helps the brand be perceived as genuinely concerned with LGBT rights and prevents a potential marginalisation of some groups by not showing any real people (e.g. alienation of the elderly or disabled consumers), it fails to 
evoke any positive feelings about the brand as it constantly forces its consumers to confront the hardships of their everyday life. Specifying whether any of these strategies provokes better responses would obviously require further studies.

\section{4. $\mathrm{RQ}_{4}$ : What is the relationship of the company with the LGBT stakeholders?}

In comparison to other brands, Ben and Jerry's address the LGBT community so frequently that it can be considered the company's main external stakeholder. It is evident, for instance, on the Polish version of the website, where the LGBT community is mentioned as early as on the main page. CSR initiatives aimed at the LGBT community contribute to such a great percentage of the company's undertakings that giving up on them could actually lead to a shift in the company's identity.

Absolut has held a high position among the LGBT community for a long time since it was one of the first companies which decided to target this group as actual external stakeholders. Absolut continuously succeeds in making the LGBT community feel like an indispensible part of their company by providing a great variety of campaigns targeted at them, making it clear that they actually know a lot about the gay culture and current political situation.

In comparison, Levi's example falls flat as the company fails to decisively and tangibly incorporate their company into the social lives of LGBT communities. If the Levi's brand decided to cut down on their support towards them, it would definitely affect NGOs financially and leave a lot of consumers disappointed. Additionally, it most probably would not have an influence on the company brand, which is not tightly connected with the cause because Levi's does not respond to specific situations opting for simple, cliché "Pride" motives instead, or because it is a more or less luxurious product which cannot be as easily obtained by less fortunate members of the LGBT community unlike ice-cream or vodka. Accordingly, Levi's failed in making the LGBT stakeholders feel like an indispensable part of their brand. Answering the question whether it affects brand loyalty or reputation would obviously require further research.

Another important aspect concerning the issue of the relationship with stakeholders is their further differentiation within one stakeholder group. While the LGBT community is a minority, it still comprises of people of different age, ethnicity, religion, social status or even gender and sexual orientation. As it was mentioned above, the people appearing in the companies' materials are ethnically varied, most often cisgender, conventionally attractive and rather young. Based on the type of the content presented by each company, Ben and Jerry's seems to target people who are politically conscious and interested in the issue of marriage equality. At the same time, Levi's and Absolut focus on the right to being oneself. Levi's in particular puts 
the biggest emphasis on the visual self-expression, while Absolut is trying to connect the image of party-oriented, young and free people (as shown in e.g. their campaign videos) with a concern with the LGBT movement history and pressing political issues (by frequent references to their long-lasting support of the community as well as openly supporting activist organisations as part of their CRM). It can be therefore stated that while Levi's and Absolut chose to mainly target young people without alienating the older generation, Ben and Jerry's decided to keep their initiatives as general as possible, only concerning themselves with issues that should interest the entire LGBT community.

\section{5. $R Q_{5:}$ What are the outcomes of CSR campaigns?}

Nowadays, most companies claim to follow the declared values. In the case of the LGBT-related CSR, the dominant rhetoric is that of freedom, respect, equality, self-expression and social justice. It is not coincidental that the aforementioned companies promote ecological, sustainable lifestyle, art, free-thinking and generally liberal political initiatives alongside with the LGBT support since all these issues are aligned with the same worldview that values individuals' rights and an all-encompassing respect above anything else. For this reason, all three companies analysed refer to more or less the same values in their "about" sections.

As it was discussed before, the LGBT audiences are prone to identify with what they see in the media, subconsciously accepting any content they receive in search for representation (Gross, 2001). While this statement is obviously a simplification, a huge influence of the media on disadvantaged minorities cannot be undermined. The simple fact of showing LGBT people on screen and granting them the acceptance of corporations (seen here as an "authority" on account of their economic supremacy), has the power to improve the image of the LGBT community in the eyes of the general public. What is more, the positive depiction of the LGBT community that has been portrayed as "immoral" and "other" for a long time can have a psychologically beneficial effect on its members.

Besides, the tangible help provided by the companies cannot be overlooked. Even though any CSR actions are meant to ultimately translate into the company profit, the donated money still helps people and organisations create a better tomorrow for the LGBT community. All of the companies investigated in this paper have provided a lot of financial support for various NGOs and supported multiple causes. Additionally, the factual political support (e.g. signing official letters or petitions) might also put pressure on the governments and, as a result, improve the quality of life of LGBT people.

However, it is important to recognise that only Ben and Jerry's fully engages in local LGBT issues, cooperating with local organisations and involving themselves in 
local political issues. In countries like Poland, where the social attitude towards the LGBT community is still rather unfavourable, the engagement of the brand makes it seem more earnest and selfless. Absolut and Levi's mostly support the American communities (e.g. the profit from Levi's "Pride Collection" from around the world still only benefits American NGOs) and fail to address the LGBT community in more controversial markets (Absolut does not conduct any LGBT-related campaigns in Poland at all, Levi's Pride Collection is limited to Europe and North America), focusing only on the more "liberal" ones (Germany, the UK). Since expectations towards the companies' social responsibility are gradually growing, the lack of the local approach might prove to be disadvantageous in the future.

\subsection{RQ6: How do LGBT-specific CSR actions influence a company's identity and reputation?}

The purpose of communicating CSR is, ultimately, to strengthen the company's identity and reputation. Building the company's identity is a long-lasting process requiring perseverance and cohesiveness.

As it was mentioned above, all three investigated companies continuously follow the narration of sustainability, fairness, equality and diversity. The LGBT support fits into these ideals and the companies managed to create a reputation of inclusive, dependable brands, which can always be trusted in terms of their ongoing support. Engaging in some of the most pressing problems of the LGBT community, e.g. HIV/AIDS crisis, marriage equality, or simply lack of general societal support, the companies gained a reputation of being strong and fearless supporters. Years of investing in these images have led up to a recognisable, solid reputation.

Following the rules of conduct supporting declarations, all of the aforementioned companies undertake real actions to help the LGBT community, e.g. by charity donations, event support or taking political stances. This solid image is what helps build the company's identity in the eyes of its LGBT stakeholders and what helps in crisis avoidance - a solid reputation is not overtly easy to be destroyed. As it was mentioned above, earning trust of the LGBT consumers contributes to the development of brand loyalty and better sales, thus the investment in identity could be called financially profitable.

However, it is important to take into account the company's not only American but also international image. Ben and Jerry's has turned out to be the only company who consistently addresses the LGBT community in all its markets, regardless of how the strong general support towards the community in a given society is. What is more, drawing on the example of Poland, their specific initiatives are tied up to the country's current political situation (e.g. "Pride" supports or "Polonez Równości"). In contrast, neither Absolut nor Levi's does extend its supportive policies to all its 
markets. For example, although Levi's does distribute its "Pride" collections in Poland, the sales are still donated to American charities and the motives of clothes are related to the American LGBT history (Stonewall riots). "Absolut Rainbow", similarly to other LGBT-oriented campaigns, has not been launched in the Polish market at all. This interferes with the main rule of identity-building, which is consistency. For this reason, it is not hard to draw the conclusion that the company's proclaimed devotion to the ideas of tolerance does not extend to the markets where such fight would be risky (and could potentially lead to a drop in sales or even a boycott). Such a policy of "safe play", while economically reasonable, fails to contribute to the creation of a genuine, steady image. The evaluation of whether the imbalance between markets could actually have a negative impact on the company's image would require further studies.

\section{Conclusion}

In conclusion, in this study we raised an issue of CCI and CRM, channels and tools, the depiction of the LGBT community, relationship with the stakeholders, outcomes of the campaigns and identity and reputation based on the case studies.

Having investigated these issues, it can be stated that the companies use $\mathrm{CCI}$ and CRM interchangeably in order to both promote their products and raise their own credibility by acting "selfless" at the same time. The channels and tools used were mostly traditional with a lesser impact placed on social media. The depiction of the LGBT community involved the political edge though the focus was placed on young people who enjoy their personal freedom. All of the aforementioned companies hold LGBT stakeholders in high regard but the degree of their perceived importance varies. The campaigns proposed by the companies might bring social change by promoting acceptance as well as factual political support and definitely provide a considerable amount of monetary benefits for charities and events but the lack of international support for the LGBT from Absolut and Levi's might seem dishonest. The support for the LGBT community is harmonised with the themes of sustainability, diversity, inclusiveness and equality and therefore contributes to the formation of the company's image, which in turn results in the acquisition of brand loyalty and strengthening of their position on the market.

All in all, the effectiveness of the aforementioned CSR actions is based on the companies' actions matching their words. The tangible, factual support, interest in political situation and continuous celebration of the LGBT community were a key to their success.

The findings of this study might serve as an inspiration or framework for further, more specific research. The topics which require further investigation and come across as particularly interesting embrace: reasons for favouring CRM over CCI, 
reasons for scarcity of interactive, social-media-based campaigns, similarities in the depiction of the LGBT community in CSR campaigns, the specific social outcomes of CSR campaigns and the opinions of LGBT stakeholders on the companies targeting them with their CSR actions. Taking into account a scarcity of relevant studies, a further investigation of the issues presented in this paper would act as a springboard for valuable, potentially innovative research, contributing to the development of a relatively unexplored subfield of corporate communication.

\section{References}

Aaker, J.L., Brumbaugh, A.M. and S.A. Grier. 2000. "Non-target markets and viewer distinctiveness: The impact of target marketing on advertising attitudes". Journal of Consumer Psychology 9.3. $1-15$.

Angelini, J.R. and S.D. Bradley. 2010. "Homosexual imagery in print advertisement: Attended, remembered, but disliked". Journal of Homosexuality 57.4. 485-502.

Anteby, M. and C. Anderson. 2014. "The shifting landscape of LGBT organizational research". Research in Organizational Behavior 34. 3-25.

Aust, P.J. 2004. "Communicated values as indicators of organizational identity: a method for organizational assessment and its application in a case study". Communication Studies 55. 515-534.

Balmer, J.M.T. and E.R. Gray. 2000. "Corporate identity and corporate communications: creating a competitive advantage". Industrial and Commercial Training 32.7. 256-262.

Brown, A.D. and M. Humphreys. 2006. "Organizational identity and place: a discursive exploration of hegemony and resistance". Journal of Management Studies 43. 231-257.

Cornelissen, J. 2004. Corporate communication: theory and practice. London: SAGE Publications Ltd.

Dörnyei, Z. 2007. Research methods in applied linguistics. New York: Oxford University Press.

Dutton, J.E., Dukerich, J.M. and C.V. Harquail. 1994. "Organizational images and member identification”. Administrative Science Quarterly 39.2. 239-263.

Fombrun, C.J. 1996. Reputation: Realizing value from the corporate image. Cambridge: Harvard Business School Press.

Freeman, R.E. 2004. "The stakeholder approach revisited". Zeitschrift für Wirtschafts- und Unternehmensethik 5.3. 228-254.

Gray, E.R. and J.M.T. Balmer. 1998. "Managing corporate image and corporate reputation.” Long Range Planning 31.5. 695-702.

Gray, R., Owen, D. and K. Maunders. 1987. Corporate social reporting: accounting and accountability. Hemel Hempstead: Prentice Hall.

Gross, L. 2001. Up from invisibility: lesbians, gay men, and the media in America. New York: Columbia University Press.

Han, X. and S.W. Tsai. 2015. "Beyond targeted advertising: representing disenfranchised minorities in 'inclusive' advertising”. Journal of Cultural Marketing Strategy 1.2. 154-169.

Hart, N.A. 1995. Effective corporate relations. Maidenhead: McGraw-Hill.

Hoffman, M.F. and D.J. Ford. 2010. Organizational rhetoric. Los Angeles: SAGE Publications, Inc.

Kenny, K., Whittle, A. and H. Willmort. 2011. Understanding identity and organizations. London: Sage Publications Ltd.

Löwensberg, D. 2006. “Corporate image, reputation and identity”. In: Tench, R. and L. Yeomans (eds). 251-264. 
Murphy, P.E., Öberseder, M. and G.R. Laczniak. 2013. "Corporate social responsibility in marketing: normatively broadening the concept". AMS Rev 3. 86-102.

Pichler, S., Blazovich, J.L., Cook, K.A., Huston, J.M. and W.R. Strawser. 2018. "Do LGBT-supportive corporate policies enhance firm performance?" Human Resources Management 57.1. 263-278.

Puppel, S. 2016. “Kuźnia Hefajstosa czyli krótki zarys teorii wizerunku w komunikacji ludzkiej”. Scripta Neophilologica Posnaniensia XVI. 109-124.

Ragins, B.R. 2004. "Sexual orientation in the workplace: the unique work and career experiences of gay, lesbian and bisexual workers." In: Martocchio, J.J. (ed.). 35-120.

Tench, R. 2006a. "Community and society: corporate social responsibility (CSR)". In: Tench, R. and L. Yeomans (eds). 94-111.

Tench, R. 2006b. "Managing community involvement programs". In: Tench, R. and L. Yeomans (eds). 354-375.

Tench, R. and L. Yeomans (eds). 2006. Exploring public relations. Harlow: Pearson Education Limited.

Van Riel, C.B.M. 1995. Principles of corporate communication. London and New York: Prentice Hall.

Van Riel, C.B.M. and C.J. Fombrun. 2007. Essentials of corporate communication. Implementing practices for effective reputation management. London and New York: Routledge.

Wąsikiewicz-Firlej, E. 2017. On (de)constructing corporate identity. An ecolinguistic approach. Poznań: Wydawnictwo Naukowe UAM.

\section{Internet sources}

IS1 https://www.icig.org.uk/the-strathclyde-statement/ (Retrieved on: 01.12.2018).

IS2 https://causemarketing.com/case-study/burger-king-proud-whopper/

IS3 https://bcorporation.net/about-b-corps

IS4 https://www.benjerry.com/

IS5 https://www.benjerry.com/values/how-we-do-business

IS6 https://benandjerrysfoundation.org/grantees/

IS7 https://www.benjerry.com/values/issues-we-care-about/marriage-equality

IS8 https://www.benjerry.pl/

IS9 https://www.benjerry.pl/blog/together-we-resist

IS10 https://www.unilever.com/sustainable-living/

IS11 https://www.unilever.com/sustainable-living/enhancing-livelihoods/

IS12 https://www.benjerry.com/whats-new/2019/03/transgender-day-of-visibility

IS13 https://www.benjerry.com/whats-new/2016/lgbtq-proposed-laws

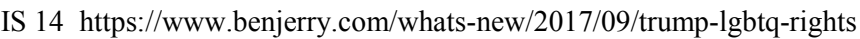

IS15 https://www.youtube.com/watch?v=IPuLOEclL8Q\&list=PLod_QHR_SXj0jKRQsOxqvA5hvNMMh97S\&index $=1$

IS16 https://twitter.com/benandjerrys/status/1112384394885505024

IS17 https://www.facebook.com/benandjerryspl/photos/fpp.617415201770947/953649321480865/?type $=3 \&$ theater

IS18 https://www.benjerry.com/about-us/jobs

IS19 https://www.unilever.com/careers/why-work-for-unilever/

IS20 https://thinkprogress.org/ben-and-jerrys-celebrates-marriage-equality-with-i-dough-i-dough-icecream-b44c813db684/

IS21 https://munchies.vice.com/en_us/article/paenz9/ben-and-jerrys-tries-to-fight-for-lgbt-rights-withstrange-ice-cream-rule

IS22 https://www.lifesitenews.com/news/love-comes-in-all-flavors-ben-jerrys-latest-push-for-gay-marria ge-is-the-we 
IS23 https://www.thedrum.com/news/2018/11/07/activism-and-ice-cream-how-ben-jerry-s-balances-so cial-causes-with-humour\#

IS24 http://www.proto.pl/aktualnosci/ben-jerrys-przywrocilo-tecze-na-plac-zbawiciela

IS25 http://warszawa.wyborcza.pl/warszawa/7,54420,24452430,jednoplciowy-polonez-na-studniowceby-wesprzec-osoby-lgbt.html

IS26 https://www.levistrauss.com/who-we-are/company/?ab=aboutusLP_values_031918

IS27 https://www.levistrauss.com/

IS28 https://www.levi.com/US/en_US/features/sustainability

IS29 https://www.levistrauss.com/values-in-action/social-impact/people/

IS30 https://www.levistrauss.com/values-in-action/social-impact/profits/

IS31 https://www.levistrauss.com/2015/02/12/love-in-levis-our-commitment-to-marriage-equality/

IS32 levistrauss.com/unzipped-blog/2016/06/10/moving-forward-with-pride/

IS33 https://www.levistrauss.com/values-in-action/levi-strauss-foundation/

IS34 https://www.levistrauss.com/2015/12/01/from-pandemic-to-progress-world-aids-day-2015/

IS35 https://www.levistrauss.com/work-with-us/life-at-lsco/diversity-inclusion/

IS36 https://www.levistrauss.com/2019/03/28/1sco-earns-another-perfect-score-hrcs-corporate-equali ty-index/

IS37 levistrauss.com/unzipped-blog/2016/06/10/moving-forward-with-pride/

IS38 https://www.levistrauss.com/2018/10/11/celebrating-coming-day-no-matter/

IS39 https://www.facebook.com/Levis/

IS40 https://witter.com/LEVIS

IS41 https://www.youtube.com/watch?v=Vw-8wie7trI\&list=PLv2owRmD8gH_s96uVz6ere1TBpwKy VBMD

IS42 https://www.out.com/fashion/truman-says/2014/06/05/daily-crush-levis-pride-2014-collection

IS43 https://www.levistrauss.com/2015/06/08/the-story-behind-the-levis-x-stonewall-pride-collection2015/

IS44 https://www.levistrauss.com/2016/05/23/the-story-behind-the-levis-x-harvey-milk-foundation-pri de-collection-2016/

IS45 https://www.levistrauss.com/2017/05/25/worn-with-pride/

IS46 https://www.levi.com/US/en_US/blog/article/levis-2018-pride-collection/

IS47 https://www.pinknews.co.uk/2017/07/01/levis-celebrates-world-pride-with-prideful-new-2017-col lection-and-lgbt-events/

IS48 https://www.bbc.com/news/uk-44500638 1/12

IS49 https://www.nytimes.com/2018/06/19/business/gay-pride-merchandise-retailers.html

IS50 http://www.theabsolutcompany.com/the-absolut-company/

IS51 https://www.absolut.com/en/news/articles/one-source-story/

IS52 https://www.youtube.com/watch?time_continue $=130 \& \mathrm{v}=02 \mathrm{e} 9 \mathrm{klKUN} 0 \mathrm{Y}$

IS53 https://www.absolut.com/en/products/absolut-rainbow/

IS54 https://www.absolut.com/pl/press/absolut-rainbow-edition/

IS55 https://www.absolut.com/p1/press/absolut-equal-love/

IS56 https://www.absolut.com/pl/press/absolut-drop/

IS57 https://www.absolut.com/de/news/articles/pride-2018/

IS58 https://www.absolut.com/uk/news/articles/kiss-with-pride/\#more-images

IS59 http://www.theabsolutcompany.com/who-we-are/\#

IS60 https://www.pernod-ricard.com/en/sr/

IS61 https://twitter.com/absolutvodka/status/1112299913143029760

IS62 https://www.youtube.com/watch?v=91LKQ8A5660

IS63 https://www.youtube.com/watch?v=JAGdLOlObAg 
IS64 https://www.youtube.com/watch?time_continue $=53 \& \mathrm{v}=\mathrm{YgHCzV} 2 \mathrm{FrSM}$

IS65 https://www.youtube.com/watch? $\mathrm{v}=\mathrm{dPwgT6G} 3 \mathrm{TZw}$

IS66 https://www.prnewswire.com/news-releases/pernod-ricard-usa-earns-top-marks-in-2018-corpora te-equality-index-300553445.html

IS67 https://www.washingtonblade.com/2011/12/22/absolut-celebrates-30-years-of-gay-ads/ 1/

IS68 https://www.thespiritsbusiness.com/2011/11/absolut\%E2\%80\%99s-outrageous-party/

IS69 www.adrespect.org/common/adlibrary/adprintdetails.cfm?QID=1286\&ClientID=11064

IS70 https://www.absolut.com/us/press/limited-editions/absolut-no-label/

IS71 marketingtherainbow.info/case studies/absolut.html

IS72 http://www.adrespect.org/common/adlibrary/adPrintdetails.cfm?QID=609\&clientID=11064

IS73 http://www.adrespect.org/common/adlibrary/adPrintdetails.cfm?QID=1276\&clientID=11064

IS74 http://www.adrespect.org/common/adlibrary/adprintdetails.cfm?QID=526\&ClientID=11064

IS75 https://mediadecoder.blogs.nytimes.com/2011/01/18/sponsorship-of-this-series-is-no-drag/

IS76 https://www.glaad.org/releases/glaad-and-absolut-vodka-celebrate-20-years-partnership 